\title{
Removal of lead (II) from synthetic and batteries wastewater using agricultural residues in batch/column mode
}

\author{
J. Singh $\cdot$ A. Ali $\cdot$ V. Prakash
}

Received: 30 January 2013/Revised: 26 April 2013/Accepted: 6 May 2013/Published online: 5 June 2013

(C) Islamic Azad University (IAU) 2013

\begin{abstract}
The present article explores the ability of five different combinations of two adsorbents (Arachis hypogea shell powder and Eucalyptus cameldulensis saw dust) to remove $\mathrm{Pb}$ (II) from synthetic and lead acid batteries wastewater through batch and column mode. The effects of solution $\mathrm{pH}$, adsorbent dose, initial $\mathrm{Pb}$ (II) concentration and contact time were investigated with synthetic solutions in batch mode. The Fourier transform infrared spectroscopy study revealed that carboxyl and hydroxyl functional groups were mostly responsible for the removal of $\mathrm{Pb}(\mathrm{II})$ ions from test solutions. The kinetic data were found to follow pseudo-second-order model with correlation coefficient of 0.99. Among Freundlich and Langmuir adsorption models, the Langmuir model provided the best fit to the equilibrium data with maximum adsorption capacity of $270.2 \mathrm{mg} \mathrm{g}^{-1}$. Column studies were carried out using lead battery wastewater at different flow rates and bed depths. Two kinetic models, viz. Thomas and Bed depth service time model, were applied to predict the breakthrough curves and breakthrough service time. The $\mathrm{Pb}$ (II) uptake capacity $\left(q_{\mathrm{e}}=540.41 \mathrm{mg} \mathrm{g}^{-1}\right)$ was obtained using bed depth of $35 \mathrm{~cm}$ and a flow rate of $1.0 \mathrm{~mL} \mathrm{~min}^{-1}$ at $6.0 \mathrm{pH}$. The results from this study showed that adsorption capacity of agricultural residues in different combinations is much better than reported by other authors, authenticating that the prepared biosorbents have potential in remediation of $\mathrm{Pb}$-contaminated waters.
\end{abstract}

J. Singh · V. Prakash $(\bowtie)$

Department of Chemistry, Maharishi Markandeshwar

University, Mullana, Ambala 133207, India

e-mail: meet2vinit@yahoo.co.in

A. Ali

School of Chemistry and Biochemistry, Thapar University,

Patiala 147004, India
Keywords Lead acid batteries wastewater - Arachis hypogea - Eucalyptus cameldulensis - Biosorbents · Bed depth service model $\cdot$ Thomas model

\section{Introduction}

Industrial activities are principally responsible for generating large volume of effluents containing hazardous species. Among these hazardous species, the heavy metals ions are most toxic and are non-biodegradable ( $\mathrm{Yu}$ 2005). Hence, their removal from aqueous effluents before being disposed in the environment is must (Jacques et al. 2007a). Amid these metal ions, lead is dominant in most of the effluent streams in India and all over the world. It is quite toxic to humans as it interacts with the sulfhydryl group of proteins, resulting in disruption of the metabolism and biological activities of different proteins in the body. It impairs hemoglobin synthesis, causes damage to liver and kidneys as well as leads to neurological disorders (Markowitz 2000). Hence, the elimination of lead from wastewater in economic and proficient way is of special concern.

Several treatment technologies have been developed to remove lead from wastewater, including ion exchange (Kopittke et al. 2007), chemical precipitation (Husein et al. 1998), electrochemical reduction (Lin and Navarro 1999), electrodialysis (Mohammadi et al. 2004), etc. However, all these methods involve high operating cost and may produce large volume of sludge. In this context, adsorption process could be helpful for the removal of $\mathrm{Pb}(\mathrm{II})$. A variety of the adsorbents have been reported in the literature for the removal of $\mathrm{Pb}(\mathrm{II})$ by waste materials of food and agricultural industry (Pehlivan et al. 2009; Saka et al. 2012).

The present research work was carried out in Haryana state of India, in 2012. In this work, the biosorption of 
$\mathrm{Pb}$ (II) from synthetic solution was done in batch mode by using five different combinations, that is, A to E (by mixing activated Eucalyptus cameldulensis saw dust and Arachis hypogea shell powder). The combination B showed best adsorption capacity as compared to other four combinations. The influence of $\mathrm{pH}$, adsorbent dose, initial metal ions concentration and contact time were studied. The obtained experimental data were evaluated and fitted using equilibrium isotherms and kinetic models. In fixed bed column operations, lead acid batteries wastewater was treated using combination B and the data were analyzed using Thomas and Bed depth service time (BDST) models.

\section{Materials and methods}

Preparation of biosorbents

Eucalyptus cameldulensis saw dust and Arachis hypogea shells were collected form Dinesh Wood Works Jagadhri and Trilok oil industry, Mustafabad (Haryana), India, respectively. Both the residues were washed extensively in deionized water to remove dirt and other particulate matter and then dried in the sun light for 7 days. Arachis hypogea shells were finally grinded separately in a vegetable grinder to obtain the biomass powder. Resulting powders were sieved through a $600-\mu \mathrm{m}$ mesh sized sieve and the powder (500 g each) thus obtained was heated in an electric hot air oven at $105{ }^{\circ} \mathrm{C}$ for $12 \mathrm{~h}$. The Eucalyptus cameldulensis saw dust (ECSD) and Arachis hypogea shell powder (AHSP) were mixed in different wt\% (Table 1). The various combinations were prepared to analyze their adsorption capacity for multimetal ion solutions.

\section{Preparation of stock solutions}

An aqueous stock solution of $\mathrm{Pb}$ (II) $\left(1,000 \mathrm{mg} \mathrm{L}^{-1}\right)$ was prepared by dissolving requisite amount of $\mathrm{Pb}\left(\mathrm{NO}_{3}\right)_{2}(\mathrm{AR}$, Loba chmie, India) in $1.0 \mathrm{~L}$ deionized water. The known amount of stock solutions were further diluted with

Table 1 Different combinations of agricultural residues

\begin{tabular}{ll}
\hline Combinations & Agricultural residues (wt\%) \\
\hline A & ECSD (10) + AHSP (90) \\
B & ECSD (30) + AHSP (70) \\
C & ECSD (50) + AHSP (50) \\
D & ECSD (70) + AHSP (30) \\
E & ECSD (90) + AHSP (10) \\
\hline
\end{tabular}

deionized water to prepare the solutions of desired concentrations. The $\mathrm{pH}$ of the solutions was adjusted by adding the appropriate amounts of $0.1 \mathrm{M} \mathrm{HCl}$ or $0.1 \mathrm{M} \mathrm{NaOH}$ solutions.

Instruments and software

The quantification of the $\mathrm{Pb}(\mathrm{II})$ in adsorbent-treated solutions has been performed on Atomic Absorption Spectrophotometer (AAS) AA630, Shimadzu, Japan. The Fourier transform infrared spectroscopy (FTIR) spectra of the adsorbent have been recorded on Thermo, Nicolet Is10 FTIR spectrophotometer, and field emission scanning electron microscopy (SEM) was performed on JEOL JSM 6510LV to collect the SEM images. The $\mathrm{pH}$ of the solution has been measured by Cyber scan, Eutch $\mathrm{pH}$ meter. The orbital shaker incubator by Metrex Scientific Instruments has been used for shaking the samples during batch operations at desired temperature and rpm. Software Sigma plot 11 has been used for the data analysis and fitting the experimental data in Thomas model.

\section{Batch studies}

Batch experiments for $\mathrm{Pb}(\mathrm{II})$ biosorption from synthetic solutions were carried out at different $\mathrm{pH}$ values, viz. 1.0-8.0, for all the metal ions by agitating a known amount of five different combinations (A to $E$ ) in 250-mL screw-cap conical flasks with adsorbent dose of $2.0 \mathrm{~g} / 0.1 \mathrm{~L}$ of metal ion solutions, respectively. The mixture so obtained was agitated in orbital shaker at $225 \mathrm{rpm}$ speed for $300 \mathrm{~min}$ at $30{ }^{\circ} \mathrm{C}$. After every $30 \mathrm{~min}$ of agitation, $2.0 \mathrm{~mL}$ of the suspensions was filtered through Whatman no. 40 filter paper and the filtrates were analyzed using AAS. Under optimized $\mathrm{pH}$, rpm and temperature, the effect of adsorbent dose ranging from 0.5 to $3.0 \mathrm{~g}$, initial metal ion concentration from 50 to $250 \mathrm{mg} \mathrm{L}^{-1}$ and contact time from 1 to $300 \mathrm{~min}$ have been studied.

The percent of the metal removal $(R \%)$ was calculated for each experiment using Eq. (1)

$R(\%)=\left[\left(C_{\mathrm{i}}-C_{\mathrm{e}}\right) / C_{\mathrm{i}}\right] \times 100$

where $C_{\mathrm{i}}$ and $C_{\mathrm{e}}$ were the initial and equilibrium concentrations of $\mathrm{Pb}$ (II) metal ions in the solution, respectively. The metal biosorption capacity $\left(q_{\mathrm{e}}=\mathrm{mg} / \mathrm{g}\right)$ of each combination for biosorption of $\mathrm{Pb}(\mathrm{II})$ metal ions at equilibrium was determined using Eq.( 2).

$q_{\mathrm{e}}=\frac{\left(C_{\mathrm{i}}-C_{\mathrm{e}}\right)}{M_{\mathrm{a}}} \times V$

where $V$ is the volume of the solution $(L)$, and $M_{\mathrm{a}}$ is the mass of the adsorbent (g) used. 


\section{Point of zero charge}

The charge on the biomass surface is a function of $\mathrm{pH}$. Point of zero charge (pHpzc) is the $\mathrm{pH}$ at which the charge of the solid surface is zero. $50 \mathrm{~mL}$ of $0.01 \mathrm{M}$ $\mathrm{NaCl}$ solution was taken in $100-\mathrm{mL}$ screw-cap conical flasks. The $\mathrm{pH}$ of each solution in each flask was adjusted to values of $2,4,6,8,10$ and 12 by adding $0.1 \mathrm{M} \mathrm{HCl}$ or $\mathrm{NaOH}$ solutions (Rivera-Utrilla et al. 2001). Then, $0.15 \mathrm{~g}$ of the combinations A to E was added separately and the final $\mathrm{pH}$ measured after $48 \mathrm{~h}$ under agitation at room temperature.

\section{The ion exchange of the combination $B$}

Among all the five combinations studied, combination B showed maximum removal capacity of $\mathrm{Pb}(\mathrm{II})$ ions in the batch studies. To identify the ions involved in the sorption of $\mathrm{Pb}(\mathrm{II})$ onto different combination used, $1.0 \mathrm{~g}$ of the combination $\mathrm{B}$ was mixed with $100 \mathrm{~mL} \mathrm{~Pb}$ (II) solution in the screw-cap conical flasks with $200 \mathrm{mg} \mathrm{L}^{-1}$ initial concentration at $\mathrm{pH}$ 6.0. The mixture so obtained was agitated in orbital shaker at $225 \mathrm{rpm}$ speed for $300 \mathrm{~min}$. After $300 \mathrm{~min}$, the mixture was centrifuged at $5,000 \mathrm{rpm}$ for $10 \mathrm{~min}$ and analyzed for the release of $\mathrm{Na}^{+}, \mathrm{K}^{+}, \mathrm{Ca}^{2+}$ and $\mathrm{Mg}^{2+}$ and unabsorbed $\mathrm{Pb}(\mathrm{II})$ ions in the solution.

\section{Blocking of carboxyl and hydroxyl functional groups}

To study the role of carboxyl $(-\mathrm{COOH})$ and hydroxyl $(-\mathrm{OH})$ in metal sorption, they were blocked in combination B (Eqs. 3, 4, respectively). To protect the carboxylic group, $9.0 \mathrm{~g}$ of the combination $\mathrm{B}$ was treated with anhydrous $\mathrm{CH}_{3} \mathrm{OH}(633 \mathrm{~mL})$ in the presence of $5.4 \mathrm{~mL} \mathrm{HCl}(5.0 \mathrm{M})$, with continuous stirring on magnetic stirrer at $225 \mathrm{rpm}$ for $360 \mathrm{~min}$. The combination B residue was then separated by centrifugation and washed thrice with deionized water to remove excess $\mathrm{CH}_{3} \mathrm{OH}$ and $\mathrm{HCl}$. The final biomass obtained was dried in hot air oven at $105{ }^{\circ} \mathrm{C}$ for $12 \mathrm{~h}$ and stored in for further use. Hydroxyl group of sorbent was protected by treating combination B with formaldehyde (Chen and Yang 2006). To do so, $5.0 \mathrm{~g}$ of the combination B was treated with HCHO $(100 \mathrm{~mL})$ under agitation on magnetic stirrer at $225 \mathrm{rpm}$ for $360 \mathrm{~min}$. The residual biomass was then separated and processed further following the same method as mentioned for the carboxylic group protection.

$$
\begin{aligned}
& \mathrm{RCOOH}+\mathrm{CH}_{3} \mathrm{OH} \rightarrow \mathrm{RCOOCH}_{3}+\mathrm{H}_{2} \mathrm{O} \\
& 2 \mathrm{R}-\mathrm{OH}+\mathrm{HCHO} \rightarrow(\mathrm{R}-\mathrm{O})_{2} \mathrm{CH}_{2}+\mathrm{H}_{2} \mathrm{O}
\end{aligned}
$$

Desorption studies

The regeneration of the adsorbent is one of the important factors in estimating its potential and feasibility for commercial use. Desorption of the adsorbed $\mathrm{Pb}$ (II) ions from the adsorbent was also studied in the batch mode. Three different desorption agents $\mathrm{HCl}, \mathrm{H}_{2} \mathrm{SO}_{4}$ and $\mathrm{HNO}_{3}$ were used in the concentration range of $0.1-0.5 \mathrm{M}$ to recover $\mathrm{Pb}$ (II) from the adsorbents (combinations A to E) and the maximum desorption was studied and compared.

\section{Characterization of lead acid batteries wastewater}

Lead acid batteries effluent was collected from Singh battery manufacturer, Yamuna Nagar, Haryana, India. Analysis of effluent showed the concentration of $\mathrm{Pb}^{2+}, \mathrm{Fe}^{2+}$ and $\mathrm{Zn}^{2+}$ as $645.15,88.20$ and $5.23 \mathrm{mg} \mathrm{L}^{-1}$, respectively.

\section{Column studies using lead acid batteries effluent}

Continuous flow experiments were conducted in glass column having $50.0 \mathrm{~cm}$ length and $1.5 \mathrm{~cm}$ internal diameter. The packing of biosorbent was done with proper care to avoid any void spaces, channels and cracks in the bed. The packed column was held vertically with the help of stand and clamp. To stabilize the process, before each run, $2.0 \mathrm{~L}$ deionized water adjusted to $\mathrm{pH} 6.0$ was passed through the columns for $12 \mathrm{~h}$ at a flow rate of $0.5 \mathrm{~mL} \mathrm{~min}^{-1}$ using peristaltic pump at room temperature. To measure the concentrations of the metal ions in the effluents of each column, $5.0 \mathrm{~mL}$ samples of the effluents was intermittently collected and analyzed. The percolation of the wastewater into each column was stopped as soon as the breakthrough point (BTP) in that particular column was achieved. Breakthrough occurs when the effluent concentration from the column is about 3-5\% of the influent concentration (Chen and Yang 2006). The column was recharged using $0.5 \mathrm{M} \mathrm{HCl}$. The wastewater was treated till the concentration of all the metal ions reached to satisfy the Central Pollution Control Board standards (CPCB 1998).

\section{Results and discussion}

Characterization of the biosorbents

The Eucalyptus cameldulensis saw dust, Arachis hypogea shells and combination B used in the column studies for the $\mathrm{Pb}$ (II) biosorption from the lead battery waste have been recovered, dried and analyzed by the FTIR and SEM instruments. 


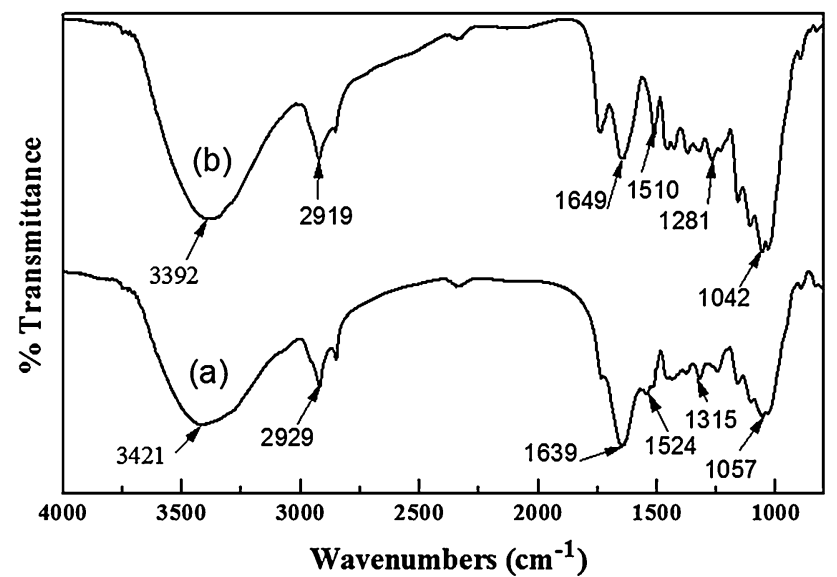

Fig. 1 FTIR spectra: a before biosorption of $\mathrm{Pb}(\mathrm{II})$ and $\mathbf{b}$ after biosorption of $\mathrm{Pb}(\mathrm{II})$ on combination $\mathrm{B}$

\section{FTIR analysis}

In order to determine the main functional groups responsible for the biosorption of $\mathrm{Pb}$ (II) from the lead battery wastewater in column studies, the combination $\mathrm{B}$ was recovered from the column, dried and subjected to the FTIR studies. The recorded spectra have been compared as shown in Fig. 1. The broad and intense peak at $3,421 \mathrm{~cm}^{-1}$ was assigned to the presence of free or hydrogen-bonded $\mathrm{O}-\mathrm{H}$ groups (from carboxylic acids or alcohols) on the surface of the adsorbent. The band at $2,929 \mathrm{~cm}^{-1}$ indicates symmetric or asymmetric $\mathrm{C}-\mathrm{H}$ stretching vibration of aliphatic acids. Peak observed at $1,649 \mathrm{~cm}^{-1}$ is the stretching vibration of $\mathrm{C}=\mathrm{O}$ functional group and may be assigned to carboxylic acids that exist in with intermolecular hydrogen bond (Vaghetti et al. 2009; Jacques et al. 2007b; Jayaram et al. 2009). The peak observed at $1,524 \mathrm{~cm}^{-1}$ is assigned to $\mathrm{C}=\mathrm{C}$ ring stretch of aromatic rings. Numerous bands ranging from 1,315 to $1,057 \mathrm{~cm}^{-1}$ refer to $\mathrm{C}-\mathrm{O}$ bonding of phenols (Jacques et al. 2007b). FTIR spectra of $\mathrm{Pb}$ (II) sorbed on combination B showed that the peaks expected at $3,421,2,929,1,639,1,524,1,315$ and $1,057 \mathrm{~cm}^{-1}$ had shifted to $3,392,2,919,1,649$ and $1,042 \mathrm{~cm}^{-1}$, respectively, attributed to $\mathrm{Pb}$ (II) ion adsorption. These groups may function as proton donors; hence, deprotonated hydroxyl and carbonyl groups may be involved in coordination with metal ions (Ashkenazy et al. 1997).

\section{Scanning electron microscopy}

Scanning electron microscopy along with energy dispersive $\mathrm{X}$-ray (EDX) analysis has been done for the characterization of the adsorbent as well as for the elucidation of the probable mechanism of adsorption. SEM images and EDX spectra obtained from fresh combination B and lead-loaded combination B are shown in Fig. 2. SEM images of fresh combination B (Fig. 2a) reveal the nature of the biomass such as rough, uneven and porous with lots of ups and down and thus make possible for the adsorption of lead ions in different parts of the biomass. Lead-loaded combination B, SEM image (Fig. 2c), is comparably bit smooth, showing the presence of $\mathrm{Pb}$ (II) on it. EDX analysis provides the elemental analysis of fresh combination $B$ and lead-loaded combination B. Figure $2 b$ indicates the presence of $\mathrm{C}$ and $\mathrm{O}$ in blank biomass. EDX spectra in Fig. 2d revealed the additional signal, which confirms the binding of the metal ions to the surface of the biomass.

Batch studies

\section{Effect of $p H$}

The $\mathrm{pH}$ of the solution has a significant impact on the uptake of metal ions, since it determines the surface charge of the biosorbent, the degree of ionization and speciation of the metal ions (Boudrahem et al. 2009; Machida et al. 2005). To study the effect of $\mathrm{pH}$ on the biosorption of $\mathrm{Pb}$ (II) ions by all five combinations, that is, $\mathrm{A}$ to $\mathrm{E}$, the batch equilibrium studies were carried out in the $\mathrm{pH}$ range of 1.0-8.0. This $\mathrm{pH}$ range was chosen to avoid metal solid hydroxide precipitation. The maximum biosorption of $\mathrm{Pb}$ (II) by all the combinations used was obtained at $\mathrm{pH} 6.0$, and a significant decrease or increase in biosorption capacity was observed at $\mathrm{pH}$ values lower or higher than 6.0. This can be explained with the help of $\mathrm{pH}_{\mathrm{PZC}}$ of the adsorbent. The $\mathrm{pH}_{\mathrm{PZC}}$ is the point where the curve $\mathrm{pH}$ final versus $\mathrm{pH}$ initial crosses the line equal to $\mathrm{pH}$ final. The $\mathrm{pH}_{\mathrm{PZC}}$ of all the five combinations (A to E) were experimentally found to be at $\mathrm{pH} 5.1,4.9,4.5,5.3$ and 5.5, respectively (Fig. 3). Further, at $\mathrm{pH}>\mathrm{pH}_{\mathrm{PZC}}$, the combinations became negatively charged and the metal species were positively charged. Under such circumstances, the electrostatic attraction between the positively charged metal ions and the negatively charged adsorbent (combinations $\mathrm{A}$ to $\mathrm{E}$ ) surface increases, consequently enhanced adsorption of the metal ions from the solution. On the other hand, at $\mathrm{pH}<\mathrm{pH}_{\mathrm{PZC}}$, the surface of the adsorbent became positively charged, resulting in a decrease in the metal ions adsorption apparently due to the higher concentration of $\mathrm{H}^{+}$ions in the solution that was challenging the positively charged metal for the active sites. The minimal adsorption was seen at $\mathrm{pH}>6$.0. It was due to the $\mathrm{Pb}$ (II) hydrolysis and precipitation, so subsequent studies were conducted at pH 6.0.

\section{Effect of contact time}

The effect of contact time on biosorption of lead on different combinations was studied in the time range of 

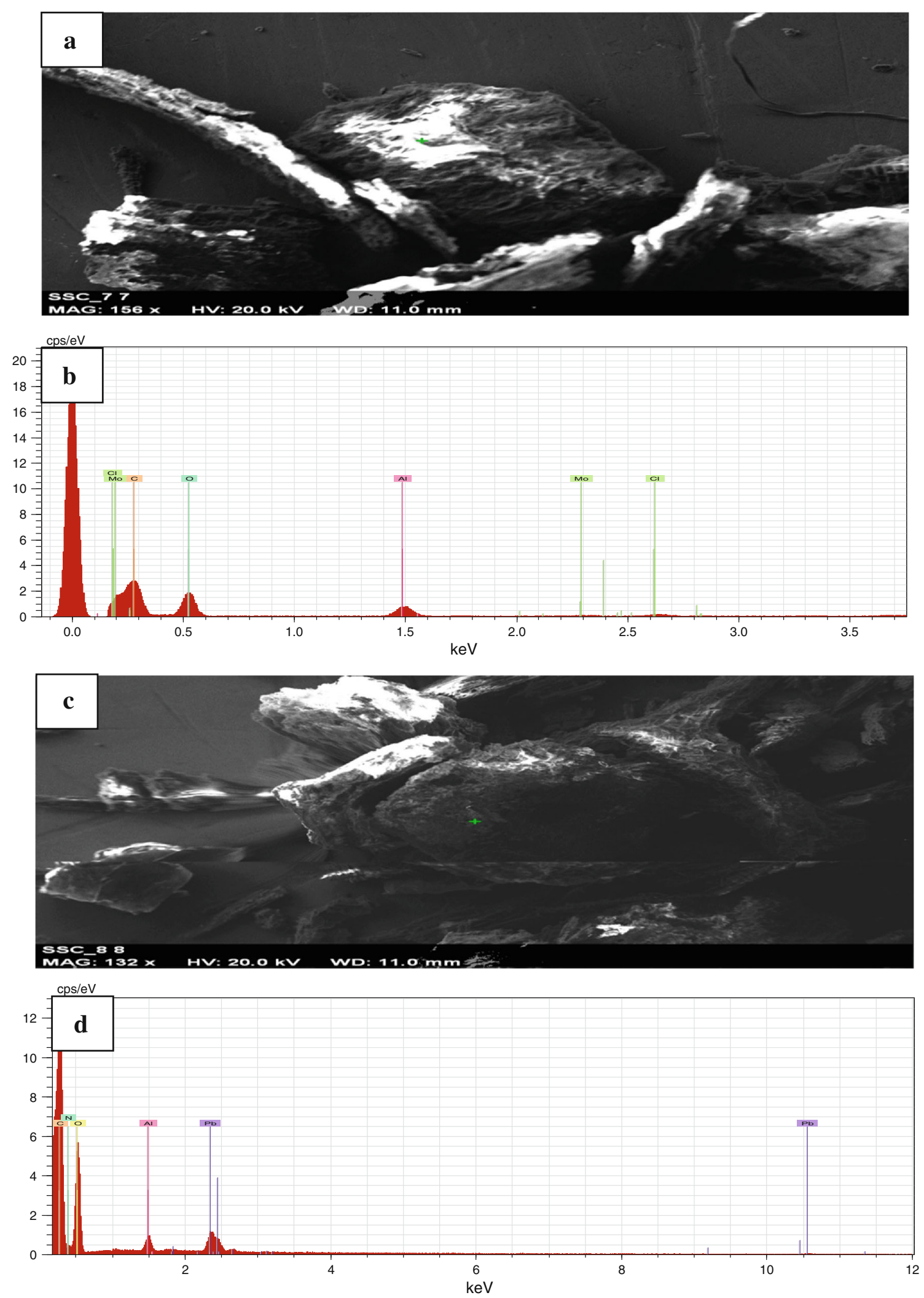

Fig. 2 SEM and EDX images of combination B before (a, b) and after (c, d) adsorption of $\mathrm{Pb}(\mathrm{II})$, respectively 


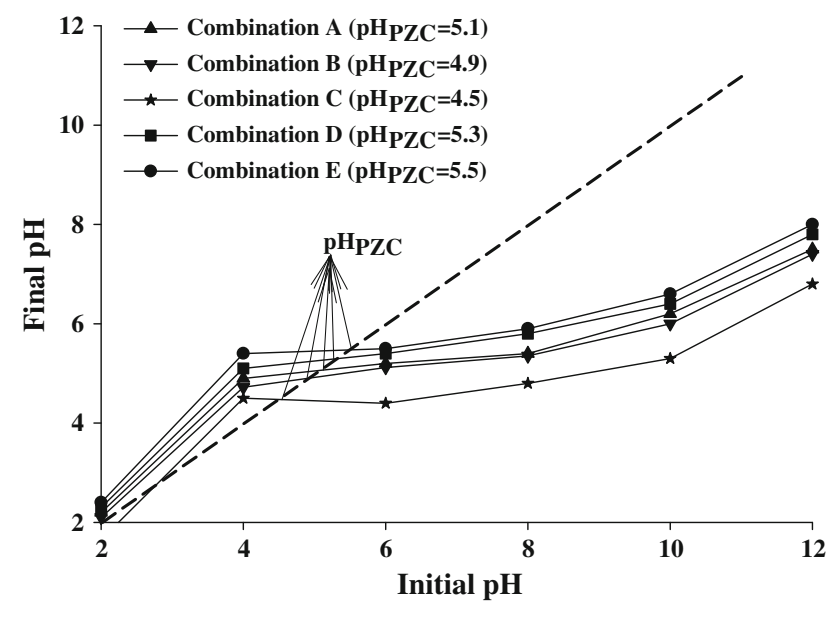

Fig. 3 Determination of pHpzc of all the combinations ( $A$ to $E$ )

1-300 min by using $200.0 \mathrm{mg} \mathrm{L}^{-1}$ of $\mathrm{Pb}$ (II) solutions at $\mathrm{pH} 6.0$ with $2.0 \mathrm{~g} / 0.1 \mathrm{~L}$ of the adsorbent. The mixture was agitated at $30{ }^{\circ} \mathrm{C}$ with $225 \mathrm{rpm}$ and the samples were taken after every $20 \mathrm{~min}$, filtered and analyzed by AAS. About $80 \%$ biosorption of $\mathrm{Pb}(\mathrm{II})$ took place in first $60 \mathrm{~min}$ and then it continued to increase at a lower rate until greater than $92 \%$, and biosorption was achieved for all the five combinations after $300 \mathrm{~min}$ of contact time. The rate of percent metal removal is higher in the beginning due to the availability of vacant-specific sites for metal ion binding. The two-stage sorption mechanism is consistent with the earlier literature reports (Boudrahem et al. 2009) which involve the first rapid and quantitatively predominant and the second slower and quantitatively insignificant step. Based on these results, a contact time of $300 \mathrm{~min}$ was assumed to be suitable for the subsequent biosorption experiments.

\section{Adsorption kinetics}

To analyze the adsorption kinetics of $\mathrm{Pb}$ (II) by all five combinations, the pseudo-first- and pseudo-second-order kinetic models were applied to the experimental data obtained. The first-order rate equation of Lagergren is one of the most widely used for the sorption of a solute from liquid solution and is represented in Eq. (5).

$\operatorname{In}\left(q_{\mathrm{e}}-q_{\mathrm{t}}\right)=\operatorname{In} q_{\mathrm{e}}-k_{1} t$

where $q_{\mathrm{t}}\left(\mathrm{mg} \mathrm{g}^{-1}\right)$ is the amount of metal ions adsorbed at time $t, q_{\mathrm{e}}$ is the amount of metal ions adsorbed at equilibrium $\left(\mathrm{mg} \mathrm{g}^{-1}\right)$, and $k_{1}$ is the rate constant of the biosorption $\left(\mathrm{min}^{-1}\right)$. The pseudo-first-order considers the rate of occupation of adsorption sites to be proportional to the number of unoccupied sites. The straight line in the graph of $\ln \left(q_{\mathrm{e}}-q_{\mathrm{t}}\right)$ versus $t$ suggests the applicability of the pseudo-first-order kinetic model. The amount of the adsorbed metal ions $\left(q_{\mathrm{e}}\right)$ and $k_{1}$ were determined from the intercept and slope of the plot, respectively, and are given in Table 2.

On the other hand, the pseudo-second-order kinetic model is based on adsorption equilibrium capacity as given in Eq. (6).

$\frac{t}{q_{\mathrm{t}}}=\frac{1}{k_{2} q_{\mathrm{e}}^{2}}+\frac{t}{q_{\mathrm{e}}}$

where $k_{2}\left(\mathrm{~g} \mathrm{mg}^{-1} \mathrm{~min}^{-1}\right)$ is the rate constant of the secondorder equation; $q_{\mathrm{t}}\left(\mathrm{mg} \mathrm{g}^{-1}\right)$ is the amount of adsorption at time $t(\mathrm{~min})$; and $q_{\mathrm{e}}$ is the amount of metal ions adsorbed at equilibrium $\left(\mathrm{mg} \mathrm{g}^{-1}\right)$.

The plot of $t / q_{\mathrm{t}}$ versus $t$ gave a straight line, and the pseudo-second-order rate constants $k_{2}$ and $q_{\mathrm{e}}$ were determined from slope and intercept of the plot, respectively, and are presented in Table 2. Among the two kinetic models used, the best fittings of the experimental values were obtained $\left(R^{2}=0.99\right)$ by following the pseudo-second-order kinetic model. This implies that the data confirm the pseudo-second-order reaction, that is, the adsorption has two phases of reaction: a very rapid biosorption for shorter duration in initial stage followed by slow one for longer duration. It has been reported that the fast reaction is due to chemisorptions involving valency forces through sharing or exchange of electrons between sorbent and sorbate and slow one is by diffusion of ions into cell structure. Hence, the rate-limiting step is chemisorptions (Singh and Ali 2012).

\section{Effect of adsorbent dose, initial Pb(II) concentration and isotherm modeling}

The equilibrium adsorption isotherm models help to establish the relationship between the amounts of metal ions adsorbed on an adsorbent and its equilibrium concentration in aqueous solution. Among various adsorption isotherms models, Langmuir and Freundlich isotherm models are preferred in this study. The Langmuir model assumes that the uptake of the metal ions occurs on a homogenous surface by monolayer adsorption without any interaction between adsorbed ions and is given by Eq. (7).

$\frac{C_{\mathrm{e}}}{q_{\mathrm{e}}}=\frac{C_{\mathrm{e}}}{q_{\max }}+\frac{1}{b q_{\max }}$

where $q_{\mathrm{e}}\left(\mathrm{mg} \mathrm{g}^{-1}\right)$ is the amount of metal ions adsorbed per unit mass of adsorbent, $C_{\mathrm{e}}$ is the equilibrium concentration in the solution $\left(\mathrm{mg} \mathrm{L}^{-1}\right)$ of $\mathrm{Pb}(\mathrm{II})$, respectively, $q_{\max }$ represents the maximum biosorption capacity $\left(\mathrm{mg} \mathrm{g}^{-1}\right)$ under the experimental conditions, and $b$ is a constant related to the affinity of the binding sites $\left(\mathrm{L} \mathrm{mg}^{-1}\right)$. 
Table 2 Pseudo-first- and second-order kinetic model for $\mathrm{Pb}(\mathrm{II})$ biosorption on different combination $(\mathrm{A}-\mathrm{E})$ at $\mathrm{pH} 6.0\left(C_{\mathrm{i}}=200 \mathrm{mg} \mathrm{L}^{-1}\right.$, adsorbent dose $=2.0 \mathrm{~g} / 0.1 \mathrm{~L}$, contact time $=300 \mathrm{~min}, \mathrm{rpm}=225$ at $30^{\circ} \mathrm{C}$ )

\begin{tabular}{lllllll}
\hline Different combinations & \multicolumn{2}{l}{ Pseudo-first-order } & & \multicolumn{3}{l}{ Pseudo-second-order } \\
\cline { 2 - 5 } & $k_{1}$ & $q_{\mathrm{e}}$ & $R^{2}$ & & $k_{2}$ & $q_{\mathrm{e}}$ \\
\hline A & 0.010 & 4.19 & 0.933 & 0.058 & 192.30 & 0.99 \\
B & 0.046 & 5.17 & 0.944 & 0.024 & 192.30 & 0.99 \\
C & 0.008 & 4.20 & 0.931 & 0.058 & 0.99 \\
D & 0.009 & 3.79 & 0.762 & 0.039 & 192.30 & 192.30 \\
E & 0.007 & 3.81 & 0.767 & 0.039 & 188.67 \\
\hline
\end{tabular}

Further, the shape of isotherm can be used to predict whether a sorption system is favorable or not. The essential features of the Langmuir isotherm can be expressed in terms of a dimensionless constant or separation factor $\left(R_{\mathrm{L}}\right)$ and the same could be defined by the Eq. (8).

$R_{\mathrm{L}}=\frac{1}{1+b C_{\mathrm{i}}}$

where $C_{\mathrm{i}}\left(\mathrm{mg} \mathrm{L}^{-1}\right)$ is the initial amount of the adsorbate in the solution, and $b\left(\mathrm{~L} \mathrm{mg}^{-1}\right)$ is the Langmuir constant described above. There are four probabilities for the $R_{\mathrm{L}}$ value, viz. for (1) favorable adsorption $0<R_{\mathrm{L}}<1$, (2) unfavorable adsorption $R_{\mathrm{L}}>1$, (3) linear adsorption $R_{\mathrm{L}}=1$ and (4) irreversible adsorption $R_{\mathrm{L}}=0$. On the other hand, Herbert Max Finley Freundlich derived an empirical adsorption isotherm equation, which is based on the biosorption on a heterogeneous surface and is given by Eq. (9).

$\operatorname{In} q_{\mathrm{e}}=\frac{1}{n} \operatorname{In} C_{\mathrm{e}}+\operatorname{In} K_{\mathrm{F}}$

where $K_{\mathrm{F}}$ and $n$ are the Freundlich constants and are indicators of adsorption capacity and adsorption intensity, respectively.

The influence of the adsorbent dose and initial $\mathrm{Pb}$ (II) concentrations on the present biosorption process was studied by employing $\mathrm{Pb}$ (II) solutions with initial concentrations in the range of $50-250 \mathrm{mg} \mathrm{L}^{-1}, \mathrm{pH} 6.0$ and adsorbent dose in the range of $0.5-3.0 \mathrm{~g} / 0.1 \mathrm{~L}$. Concentrations of $\mathrm{Pb}(\mathrm{II})$ from each batch were measured at equilibrium. Both Langmuir and Freundlich isotherms were applied to the data obtained, and it was seen that increase in adsorbent dose from 0.5 to $3.0 \mathrm{~g} / 0.1 \mathrm{~L}$ resulted in a rapid increase in the uptake of $\mathrm{Pb}$ (II) ions. But no significant increase in adsorption was found beyond $2.0 \mathrm{~g} / 0.1 \mathrm{~L}$. It could be attributed to the presence of excess/surplus metal binding sites on the combination $\mathrm{B}$ than the available $\mathrm{Pb}$ (II) ions, or in other words, decrease in adsorption capacity could be due to the overlapping of the adsorption sites as a result of overcrowding of the adsorbent particles when the adsorbent dosage is increased above $2.0 \mathrm{~g} / 0.1 \mathrm{~L}$. This imposed a screening effect on the dense outer layer of the adsorbent, thereby shielding the binding sites from metals as explained by Babel and Kurniawan (2004). However, when the initial concentration of $\mathrm{Pb}$ (II) was continuously increased from 50 to $250 \mathrm{mg} \mathrm{L}^{-1}$ using the fixed amount of the adsorbent $(2.0 \mathrm{~g} / 0.1 \mathrm{~L})$, the biosorption of the $\mathrm{Pb}(\mathrm{II})$ was found to decrease due to the early saturation of the binding sites of the biosorbent at high $\mathrm{Pb}$ (II) concentration. This may also be attributed to the increase in the number of $\mathrm{Pb}$ (II) competing for available binding sites of the adsorbent. The Langmuir and Freundlich constants and their correlation coefficients $\left(r^{2}\right)$ evaluated from these isotherms for $\mathrm{Pb}$ (II) are given in Table 3.

The sorption characteristics of $\mathrm{Pb}$ (II) on the combination B followed more closely the Langmuir isotherm model with $q_{\max }=270.2 \mathrm{mg} \mathrm{L}^{-1}$ than the Freundlich isotherm model. This observation is further supported by the assessment of the respective correlation coefficient values which are a measure of how well the theoretical values match with the experimental data. Also, the values of $R_{\mathrm{L}}$ were calculated using Eq. (6) with $\mathrm{Pb}$ (II) concentrations in the range of $50.0-250.0 \mathrm{mg} \mathrm{L}^{-1}$ and were found to fall between zero and one which is again an indication of the favorable biosorption for $\mathrm{Pb}$ (II) on all the five combinations used. The value of $n$, which is related to the distribution of bonded ions on adsorbent surface, represents beneficial adsorption if it is between 1 and 10 (Kadirvelu and Namasivayan 2000). The value of $n$ was found to be $>1$, indicating that the adsorption of $\mathrm{Pb}$ (II) was favorable under studied conditions.

\section{Comparison of the combination $B$ with other adsorbents}

The adsorption capacity values of various adsorbents used for $\mathrm{Pb}$ (II) adsorption have been shown in Table 4. The comparison between present results and with that of the literature reported one shows that agricultural residues used in combination in the present study exhibit very good sorption efficiency. The maximum biosorption capacity $\left(q_{\max }\right)$ was found to be $270.2 \mathrm{mg}$ for $\mathrm{Pb}(\mathrm{II})$ when $2.0 / .01 \mathrm{~L}$ of the combination B was used at $\mathrm{pH} 6.0$, and this value is relatively better than most of the earlier reported results as 
Table 3 Langmuir and Freundlich isotherm constants and correlation coefficients for the biosorption of $\mathrm{Pb}$ (II) on combination $\mathrm{B}$ at $\mathrm{pH} 6.0$ with different adsorbent doses (contact time $=300 \mathrm{~min}, \mathrm{rpm}=225$ at $30{ }^{\circ} \mathrm{C}$ )

\begin{tabular}{|c|c|c|c|c|c|c|}
\hline \multirow[t]{2}{*}{ Wt. of combination B (g) } & \multicolumn{3}{|l|}{ Langmuir } & \multicolumn{3}{|l|}{ Freundlich } \\
\hline & $q_{\max }\left(\mathrm{mg} \mathrm{g}^{-1}\right)$ & $b\left(\mathrm{~L} \mathrm{mg}^{-1}\right)$ & $R^{2}$ & $n\left(\mathrm{mg} \mathrm{g}^{-1}\right)$ & $K_{\mathrm{F}}$ & $R^{2}$ \\
\hline 0.5 & 222.2 & 0.123 & 0.97 & 3.9 & 4.13 & 0.98 \\
\hline 1.0 & 238.1 & 0.143 & 0.96 & 4.8 & 4.42 & 0.93 \\
\hline 1.5 & 250.0 & 0.286 & 0.99 & 4.6 & 4.55 & 0.99 \\
\hline 2.0 & 270.2 & 0.840 & 0.99 & 4.8 & 4.73 & 0.84 \\
\hline 2.5 & 263.2 & 1.15 & 0.94 & 2.5 & 4.01 & 0.92 \\
\hline 3.0 & 222.2 & 1.28 & 0.99 & 2.7 & 3.99 & 0.92 \\
\hline
\end{tabular}

Table 4 Comparison of maximum adsorption capacity of $\mathrm{Pb}(\mathrm{II})$ on different adsorbents in the literature

\begin{tabular}{|c|c|c|c|c|}
\hline Adsorbents & $\begin{array}{l}\text { Mass of } \\
\text { adsorbent } \\
\left(\mathrm{g} \mathrm{L}^{-1}\right)\end{array}$ & $\mathrm{pH}$ & $\begin{array}{l}\text { Adsorption } \\
\text { capacity } \\
\left(\mathrm{mg} \mathrm{g}^{-1}\right)\end{array}$ & References \\
\hline Barely & 6.25 & 6.0 & 23.20 & $\begin{array}{l}\text { Pehlivan et al. } \\
\text { (2009) }\end{array}$ \\
\hline Snowberry & 4.0 & 5.5 & 62.16 & $\begin{array}{l}\text { Akara et al. } \\
\text { (2009) }\end{array}$ \\
\hline Rice husk & 3.0 & 6.0 & 58.1 & $\begin{array}{l}\text { Krishnani et al } \\
(2008)\end{array}$ \\
\hline Pecan nutshell & 4.0 & 5.5 & 211.7 & $\begin{array}{l}\text { Vaghetti et al. } \\
\text { (2009) }\end{array}$ \\
\hline Macrofungus & 4.0 & 5.0 & 38.4 & $\begin{array}{l}\text { Sari and Tuzen } \\
\text { (2009) }\end{array}$ \\
\hline Sawdust & 7.5 & 5.0 & 88.49 & $\begin{array}{l}\text { Naiya et al. } \\
\text { (2008) }\end{array}$ \\
\hline $\begin{array}{l}\text { Pinus sylvestris } \\
\text { sawdust }\end{array}$ & 1.0 & 5.0 & 22.22 & $\begin{array}{c}\text { Taty-Costodes } \\
\text { et al. (2003) }\end{array}$ \\
\hline $\begin{array}{l}\text { Combination } \\
\text { B (ECSD }(30 \%) \\
+ \text { AHSP }(70 \%))\end{array}$ & 2.0 & 6.0 & 272.2 & Present work \\
\hline
\end{tabular}

given in Table 4. Further additional advantages of ECSD and AHSP are their easy availability and cost effectiveness, which make them better biosorbent for the removal of $\mathrm{Pb}$ (II) in different combinations from aqueous systems.

\section{The ion-exchange capacity of the combination $B$}

More than $91 \%$ removal of $\mathrm{Pb}(\mathrm{II})$ was due to the ionexchange process involving $\mathrm{Na}^{+}, \mathrm{K}^{+}, \mathrm{Ca}^{2+}$ and $\mathrm{Mg}^{2+}$. The remaining $9 \% \mathrm{~Pb}$ (II) adsorption could be due to its ion exchange with protons, as $\mathrm{pH}$ of the supernatant was found to decrease at equilibrium. Hence, it may be concluded that the sorption process for $\mathrm{Pb}$ (II) on combination $\mathrm{B}$ occurs primarily through ion-exchange mechanism involving the replacement of alkali and alkaline earth metals. The protons bound to native carboxylate groups are also involved in ion-exchange process but to the lesser extent. Similar type of ion-exchange mechanism has also been reported and discussed for other agrowaste materials (Naiya et al. 2008).

\section{Blocking of functional groups and computation of their role in metal sorption}

To confirm and compute the role of carboxyl and hydroxyl groups in the removal of $\mathrm{Pb}(\mathrm{II})$, both the groups of the combination B were individually blocked in two separate experiments. It was observed that the metal removal capacity was badly inhibited when carbonyl groups were blocked and a decrease of $70.5 \%$ in the adsorption of $\mathrm{Pb}$ (II) was observed. It clearly indicates that the carboxyl groups have the major role in the process of adsorption. On the other hand, $29.5 \%$ of $\mathrm{Pb}(\mathrm{II})$ was removed by combination $\mathrm{B}$, even after the blockage of carboxyl groups, indicating that other functional groups are also involved in adsorption of metal ions. To support the presence of other functional groups on the adsorbent, sorption of $\mathrm{Pb}$ (II) by combination B was carried out after blocking the hydroxyl groups. The adsorption capacity of the hydroxyl groupblocked adsorbent A was found to decrease $32.8 \%$ for the removal of $\mathrm{Pb}(\mathrm{II})$. Further, the total metal uptake capacity of carboxylic and hydroxyl group-blocked adsorbent together was found to be almost equal to the total metal ions uptake by unblocked adsorbent. These results along with the functional groups study of adsorbent by the FTIR technique (Fig. 1) support that carboxyl and hydroxyl groups are mainly responsible for the uptake of $\mathrm{Pb}$ (II) by combination B.

\section{Desorption studies}

The $15.0 \mathrm{~g}$ of the combination B loaded with $\mathrm{Pb}(\mathrm{II})$ was collected and dried in an electric hot air oven at $105{ }^{\circ} \mathrm{C}$ for $12 \mathrm{~h} ; 1.0 \mathrm{~g}$ of it was mixed with each $100 \mathrm{~mL}$ of $\mathrm{HCl}$ with varying concentration $(0.1-0.5 \mathrm{M})$ in $250-\mathrm{mL}$ screw-cap conical flasks. The mixtures so obtained were agitated in orbital shaker at $225 \mathrm{rpm}$ speed for $300 \mathrm{~min}$ at $30{ }^{\circ} \mathrm{C}$. After 
300 min of agitation, the suspensions were filtered through Whatman no. 40 filter paper and the filtrates were analyzed for $\mathrm{Pb}(\mathrm{II})$ using AAS. Same procedure was repeated with $\mathrm{H}_{2} \mathrm{SO}_{4}$ and $\mathrm{HNO}_{3}$. It was seen that the desorption efficiency increased with increase in the concentration from 0.1 to $0.5 \mathrm{M}$ of desorption agents, viz. $\mathrm{HCl}, \mathrm{H}_{2} \mathrm{SO}_{4}$ and $\mathrm{HNO}_{3}$. Furthermore, it was noticed that $\mathrm{HCl}$ gave maximum desorption, about $99 \%$ as compared to $\mathrm{H}_{2} \mathrm{SO}_{4}$ $(83 \%)$ and $\mathrm{HNO}_{3}(74 \%)$. The reusability of the combination $\mathrm{B}$ was tested in three consecutive adsorptiondesorption cycles in batch mode, and the results suggested that the combination $\mathrm{B}$ has the potential to be used repeatedly for $\mathrm{Pb}(\mathrm{II})$ adsorption without much significant loss in total adsorption capacity.

\section{Column studies}

In this article, the effect of bed depth and flow rate on the breakthrough curves was investigated using bed depths of 25,30 and $35 \mathrm{~cm}$ made by the uniform packing of 12,14 and $16 \mathrm{~g}$, respectively, of the combination $\mathrm{B}$. The lead acid batteries effluent containing $\mathrm{Pb}$ (II), $\mathrm{Fe}$ (II) and $\mathrm{Zn}$ (II) metal ions with $\mathrm{pH}$ adjusted 6.0 was passed through the columns at the flow rate of $1.0,2.0$ and $5.0 \mathrm{~mL} \mathrm{~min}^{-1}$.

Batch biosorption assays give fundamental information related to biosorption equilibrium and kinetics. However, in most industrial aqueous treatment units, a continuous flow biosorption experiments are preferred. Therefore, continuous biosorption experiments were conducted in fixed bed columns. The overall performance of the column is usually described through the concept of breakthrough curve, which is obtained by plotting the measured effluent concentration divided by the influent concentration $\left(C_{\mathrm{e}} / C_{\mathrm{i}}\right)$ versus time $(t)$. The column performance was studied by varying the flow rate and bed height at specific metal ion concentration.

\section{Effect of effluent flow rate}

Flow rate of the column could alter the residence time of the metal solution in the column and hence is an important parameter that could influence the sorption capacity of the biosorbent in fixed bed operations. To explore the effect of flow rate on $\mathrm{Pb}$ (II) biosorption, the lead battery wastewater with $645.15 \mathrm{mg} \mathrm{L}^{-1} \mathrm{~Pb}(\mathrm{II})$ initial concentration was passed through the column with fixed bed depth of $25 \mathrm{~cm}$ at pH 6.0 with different flow rates of 1.0, 2.0 and $5.0 \mathrm{~mL} \mathrm{~min}^{-1}$. As shown in Fig. 4, the column performance was found to be better at lower flow rate. An earlier breakthrough and column exhaustion times were achieved, when the flow rate was increased from 1.0 to $5.0 \mathrm{~mL} \mathrm{~min}{ }^{-1}$. This behavior could be due to the decrease in the residence time, which restricted the contact of metal solution to the biosorbent (Singh and Ali 2012). Moreover, at higher flow rates, the metal ions did not have enough time to diffuse into the biosorbent and they leave the column before equilibrium occurred resulting in low metal uptake and which results in earlier breakthrough curves. At lower flow rates, the residence time of the metal solution in the column was increased, and hence, metal ions have enough time to diffuse into the biosorbent through intraparticle diffusion and resulting late breakthrough curves.

To predict the adsorption behavior of $\mathrm{Pb}(\mathrm{II})$ onto the combination B-packed fixed bed columns, the data obtained were analyzed by Thomas model as it is one of the most general and widely used models to explain the column performance theory. The Thomas model assumes the Langmuir kinetics of sorption and desorption, with no axial dispersion. It assumes that the rate-driving force in sorption obeys second-order reversible reaction kinetics (Thomas 1944).

The expression by Thomas, for the adsorption by column, is given as follows in Eq. (10).

$\frac{C_{\mathrm{e}}}{C_{\mathrm{i}}}=\frac{1}{1+\exp \left(\frac{k_{\mathrm{TH}} q_{\mathrm{e}} s}{R}-k_{\mathrm{TH}} C_{\mathrm{i}} t\right)}$

where $k_{\mathrm{TH}}$ is the Thomas rate constant $\left(\mathrm{mL} \mathrm{min}^{-1} \mathrm{mg}^{-1}\right)$, $q_{\mathrm{e}}$ the maximum metal uptake per gram of the adsorbent $\left(\mathrm{mg} \mathrm{g}^{-1}\right), s$ the amount of adsorbent in gram in the column, $C_{\mathrm{i}}$ and $C_{\mathrm{e}}$ are the influent and the effluent concentrations $\left(\mathrm{mg} \mathrm{L}^{-1}\right)$ of the metal ions, respectively, at time $t$ ( $\mathrm{min}$ ), and $t=V_{\text {eff }} / R$ where $V_{\text {eff }}$ is the effluent volume $(\mathrm{mL})$ and $R$ is the flow rate $\left(\mathrm{mL} \min ^{-1}\right)$. The values of $k_{\mathrm{TH}}$ and $q_{\mathrm{e}}$ were determined from the plot of $\mathrm{C}_{\mathrm{e}} / \mathrm{C}_{\mathrm{i}}$ against time $t$ using nonlinear regression analysis.

The value of the regression coefficient $\left(R^{2}>0.99\right)$ as given in Table 5 indicates that the model describes the column performance data very well for the biosorption of $\mathrm{Pb}$ (II), $\mathrm{Fe}(\mathrm{II})$ and $\mathrm{Zn}$ (II) in all three sorption cycles. It was

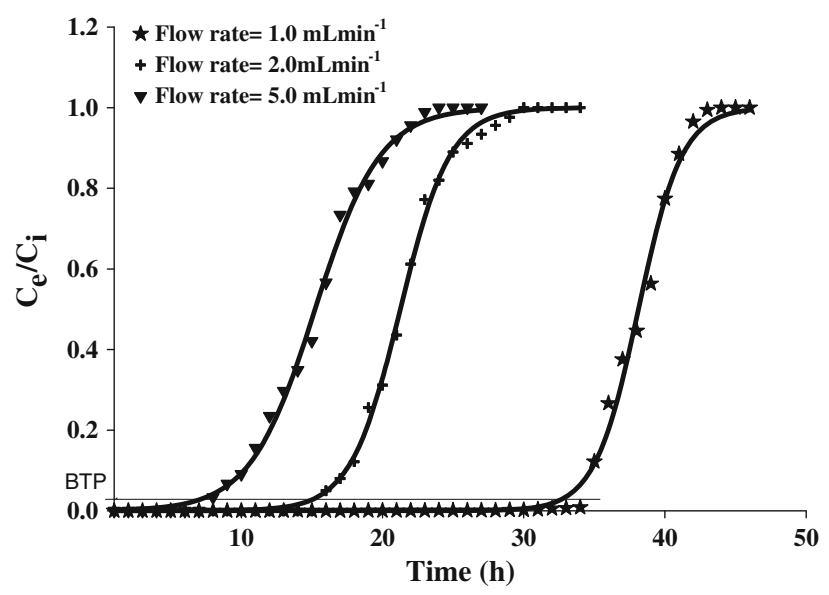

Fig. 4 Effect of flow rates on $\mathrm{Pb}$ (II) biosorption by combination B-packed fixed bed column at $\mathrm{pH} 6.0\left(C_{\mathrm{i}}=645.15 \mathrm{mg} \mathrm{L}^{-1}\right.$, bed depth $=25.0 \mathrm{~cm}$ ) 
also found that the experimental and model predicted normalized values at experimental conditions were very close. Further, the metal uptake capacity found to decrease $\left(q_{\mathrm{e}}=512.45-204.74 \mathrm{mg} \mathrm{g}^{-1}\right)$ in the successive cycles, whereas Thomas rate constant did not change significantly. This behavior was primarily attributed to gradual deterioration and depletion of binding sites caused by the acidic elution and continuous usage, or it might be due to blocking of the active sites for solute uptake by the organic moieties present in the lead battery effluents (Vinodhini and Das 2010). The effluent from first cycle showed complete biosorption of all three metals ions satisfying the Central Pollution Control Board standards (CPCB 1998) and making that water fit for reuse.

\section{Effect of bed depth}

The biosorption of the metal ions in fixed bed column studies is dependent on the quantity of biosorbent in the column. The continuous biosorption experiments were performed, at three different bed depths of 25, 30 and $35 \mathrm{~cm}$, achieved by taking 12,14 and $16 \mathrm{~g}$ of the combination $\mathrm{B}$, in the columns as given in Fig. 5. The flow rate and initial $\mathrm{Pb}(\mathrm{II})$ concentration were kept constant at $1.0 \mathrm{~mL} \mathrm{~min}^{-1}$ and $645.15 \mathrm{mg} \mathrm{L}^{-1}$, respectively, during the experiments. The shapes and gradient of the breakthrough curves change with the increase in bed depth from 25 to $35 \mathrm{~cm}$. The metal ion concentration in the effluent was found to increase as the breakthrough time was reached and same was indicated by the sharp increase in the slope in each of the curves. The breakthrough time of $35.0 \mathrm{~h}$ was observed when the column of low bed depth of $25 \mathrm{~cm}$ was used for the biosorption study of $\mathrm{Pb}(\mathrm{II})$. On increasing the bed depth from 25 to $35 \mathrm{~cm}$, the breakthrough time was found to increase from 35.0 to $47.0 \mathrm{~h}$ and metal uptake capacity $q_{\mathrm{e}}$ from 512.45 to $540.41 \mathrm{mg} \mathrm{g}^{-1}$. This observation could be explained by considering the fact that with low bed depth, the metal ions do not have enough time to diffuse into the whole of the biosorbent mass, due to which the breakthrough time was achieved earlier by the column. However, the increase in bed depth of the column leads to increase the residence time of solution in the

Table 5 Thomas model parameters calculated constants for the $\mathrm{Pb}$ (II) biosorption by combination $\mathrm{B}$ at different bed depth and flow rates $\left(C_{\mathrm{i}}=645.15, \mathrm{pH}=6.0\right)$

\begin{tabular}{lllll}
\hline$R\left(\mathrm{~mL} \mathrm{~min}^{-1}\right)$ & $S(\mathrm{~g})$ & $k_{\mathrm{Th}}\left(\mathrm{mL} \mathrm{min}^{-1} \mathrm{mg}^{-1}\right)$ & $q_{\mathrm{e}}\left(\mathrm{mg} \mathrm{g}^{-1}\right)$ & $R^{2}$ \\
\hline 1.0 & 12.0 & 0.001 & 512.45 & 0.99 \\
2.0 & 12.0 & 0.009 & 285.76 & 0.99 \\
5.0 & 12.0 & 0.007 & 204.74 & 0.99 \\
1.0 & 14.0 & 0.007 & 514.37 & 0.99 \\
1.0 & 16.0 & 0.005 & 540.41 & 0.99 \\
\hline
\end{tabular}

column and allowing the metal ions to diffuse deeper inside the biosorbent. Hence, higher values of the breakthrough time and $q_{\mathrm{e}}$ were achieved when a column of higher bed depth was used for the biosorption study.

The BDST model is one of the mathematical models proposed by Hutchins (1973), which states that bed depth (Z) and breakthrough service time $\left(t_{\mathrm{b}}\right)$ of a column bear a linear relationship. The equation can be expressed as follows:

$t_{\mathrm{b}}=\left(\frac{N_{\mathrm{o}}}{C_{\mathrm{i}} R}\right) Z-\left(\frac{1}{K_{\mathrm{a}} C_{\mathrm{i}}}\right) \operatorname{In}\left(\frac{C_{\mathrm{i}}}{C_{\mathrm{b}}}-1\right)$

where $\mathrm{C}_{\mathrm{b}}\left(\mathrm{mg} \mathrm{L} \mathrm{L}^{-1}\right)$ is the breakthrough metal ion concentration, $N_{\mathrm{o}}\left(\mathrm{mg} \mathrm{L}^{-1}\right)$ is the adsorption capacity, $K_{\mathrm{a}}$ $\left(\mathrm{L} \mathrm{mg}^{-1} \mathrm{~h}^{-1}\right)$ is the rate constant in BDST model, and the $R\left(\mathrm{~mL} \mathrm{~min}^{-1}\right)$ is the flow rate. Equation (11) could be written in the form of the following Eq. (12):

$t_{\mathrm{b}}=m Z-K$

where $m$ is the slope of the BDST line $\left(m=N_{\mathrm{o}} / C_{\mathrm{i}} R\right)$, and $K$ is the intercept of this equation.

$K=\frac{1}{k_{\mathrm{a}} C_{\mathrm{i}}}\left(\operatorname{In} \frac{C_{\mathrm{i}}}{C_{\mathrm{b}}}-1\right)$

A plot of $t_{\mathrm{b}}$ versus $Z$ at flow rate of $1.0 \mathrm{~mL} \mathrm{~min}^{-1}$ was linear $\left(R^{2}=1.0\right)$, indicating the validity of BDST model for the present system. The values of adsorption capacity $N_{\mathrm{o}}$ and rate constant $K_{\mathrm{a}}$ were evaluated from the slope and intercept of the plot and found to be $774.18 \mathrm{mg} \mathrm{L}^{-1}$ and $0.0006 \mathrm{~L} \mathrm{mg}^{-1} \mathrm{~h}^{-1}$, respectively. The value of $K_{\mathrm{a}}$ could be used to describe the capacity of biosorption column. A large value of $K_{\mathrm{a}}$ indicates that even a short bed could circumvent breakthrough, but as $K_{\mathrm{a}}$ decreases, a longer bed is required (Singh and Ali 2012) for maximum biosorption of the metal ions.

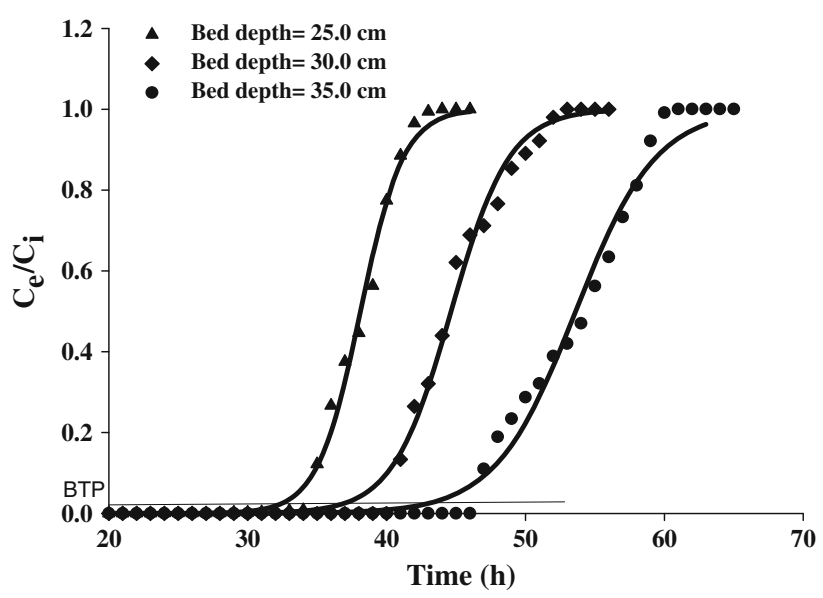

Fig. 5 Effect of bed depth on $\mathrm{Pb}$ (II) biosorption by combination B-packed fixed bed column at pH $6.0\left(C_{\mathrm{i}}=645.15 \mathrm{mg} \mathrm{L}^{-1}\right.$, flow rate $=1.0 \mathrm{~mL} \mathrm{~min}^{-1}$ ) 


\section{Conclusion}

The present article concludes that agricultural residues, viz. Eucalyptus cameldulensis saw dust and Arachis hypogea shell powder, used in different combinations have an excellent potential for the biosorption of $\mathrm{Pb}$ (II) from synthetic as well as lead battery effluents. The adsorption process was a function of $\mathrm{pH}$, adsorbent dose, initial metal ion concentration and contact time. The effective $\mathrm{pH}$ for $\mathrm{Pb}$ (II) removal was found to be 6.0. Adsorption kinetics was found to follow pseudo-second-order kinetic model, and the equilibrium sorption data were satisfactorily fitted to Langmuir adsorption isotherms. Among the five different combinations used, combination B showed maximum biosorption capacity $\left(q_{\max }=270.2 \mathrm{mg} \mathrm{g}^{-1}\right)$ in batch mode. FTIR spectra analysis showed that the carboxyl and hydroxyl groups were the principal functional groups responsible for sorption of $\mathrm{Pb}(\mathrm{II})$ ions. The chemical blocking of the carboxyl and hydroxyl groups verified their participation in the metal sorption process. Further, the discharge of nearly equal amount of $\mathrm{Na}^{+}, \mathrm{K}^{+}, \mathrm{Ca}^{2+}, \mathrm{Mg}^{2+}$ and $\mathrm{H}^{+}$during the uptake of $\mathrm{Pb}$ (II) ions showed that the adsorption process was entirely ion exchange. The column studies were carried out for treating lead battery effluent. Thomas and BDST models were applied to the data obtained, and the maximum metal uptake capacity $\left(q_{\mathrm{e}}=540.41 \mathrm{mg} \mathrm{g}^{-1}\right)$ was obtained at flow rate of

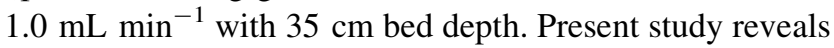
that the biosorbents used in different combinations are quite effective for the removal of different metal ions from the lead battery wastewater in continuous flow studies. The results obtained would be useful for the design of wastewater treatment plant for industrial purposes.

Acknowledgments Authors acknowledge the financial support from the CSIR, New Delhi (Ref. No.: 01(2503)/11/EMR-II), and School of Chemistry and Biochemistry, Thapar University-Patiala, India, for providing the necessary research facilities.

\section{References}

Akara ST, Gorgulu A, Anilan B, Kaynak Z, Akara T (2009) Investigation of the biosorption characteristics of lead(II) ions onto Symphoricarpus albus: batch and dynamic flow studies. J Hazard Mater 165:126-133

Ashkenazy R, Gottlieb L, Yannai S (1997) Characterization of acetone-washed yeast biomass functional groups involved in lead biosorption. Biotechnol Bioeng 55:1-10

Babel S, Kurniawan TA (2004) Cr(VI) removal from synthetic wastewater using coconut shell charcoal and commercial activated carbon modified with oxidizing agents and/or chitosan. Chemosphere 54:951-967

Boudrahem F, Aissani-Benissad F, Ait-Amar H (2009) Batch sorption dynamics an equilibrium for the removal of lead ions from aqueous phase using activated carbon developed from coffee residue activated with zinc chloride. J Environ Manag 90:3031-3039

Chen JP, Yang L (2006) Study of a heavy metal biosorption onto raw and chemically modified Sargassum sp. via spectroscopic and modeling analysis. Langmuir 22:8906-8914

CPCB (1998) Pollution control acts, rules, and notification issued hereunder, Central Pollution Control Board, Ministry of Environment and Forests, New Delhi, 501: 311-312

Husein MM, Vera JH, Weber ME (1998) Removal of lead from aqueous solutions with sodium caprate. Sep Sci Technol 33:1889-1904

Hutchins RA (1973) New method simplifies design of activated carbon system. Chem Eng 80:133-135

Jacques RA, Bernardi R, Caovila M, Lima EC, Pavan FA, Vaghetti JCP, Airoldi C (2007a) Removal of $\mathrm{Cu}(\mathrm{II}), \mathrm{Fe}$ (III) and $\mathrm{Cr}$ (III) from aqueous solution by aniline grafted silica gel. Sep Sci Technol 42:591-609

Jacques RA, Lima EC, Dias SLP, Mazzocato AC, Pavan FA (2007b) Yellow passion fruit shell as biosorbent to remove $\mathrm{Cr}(\mathrm{III})$ and $\mathrm{Pb}$ (II) from aqueous solution. Sep Purif Technol 57:193-198

Jayaram K, Murthy IYLN, Lalhruaitluanga H, Prasad MNV (2009) Biosorption of lead from aqueous solution by seed powder of Strychnos potatorum L. Colloid Surf B 71:248-254

Kadirvelu K, Namasivayan C (2000) Agricultural by-products as metal adsorbents: sorption of lead (II) from aqueous solutions onto coir-pith carbon. Environ Technol 21:1091-1097

Kopittke PM, Asher CJ, Kopittke RA, Menzies NW (2007) Toxic effects of $\mathrm{Pb}^{2+}$ on growth of cowpea (Vigna unguiculata). Environ Pollut 150:280-286

Krishnani KK, Meng X, Christodoulatos C, Boddu VM (2008) Biosorption mechanism of nine different heavy metals onto biomatrix from rice husk. J Hazard Mater 153:1222-1234

Lin SW, Navarro RMF (1999) An innovative method for removing $\mathrm{Hg}^{2+}$ and $\mathrm{Pb}^{2+}$ in ppm concentrations from aqueous media. Chemosphere 39:1809-1817

Machida M, Yamazaki R, Aikawa M, Tatsumoto H (2005) Role of minerals in carbonaceous adsorbents for removal of $\mathrm{Pb}$ (II) ions from aqueous solution. Separ Purif Technol 46:88-94

Markowitz M (2000) Lead poisoning. Pediatr Rev 10:327-335

Mohammadi T, Razmi A, Sadrzadeh M (2004) Effect of operating parameters on $\mathrm{Pb}^{2+}$ separation from wastewater using electrodialysis. Desalination 167:379-385

Naiya TK, Bhattacharya AK, Das SK (2008) Adsorption of Pb(II) by sawdust and neem bark from aqueous solutions. Environ Prog 27:313-328

Pehlivan E, Altun T, Parlayıc S (2009) Utilization of barley straws as biosorbents for $\mathrm{Cu}^{2+}$ and $\mathrm{Pb}^{2+}$ ions. J Hazard Mater 164: 982-986

Rivera-Utrilla J, Bautista-Toledo I, Ferro-Garcy'a MA, MorenoCastilla C (2001) Activated carbon surface modifications by adsorption of bacteria and their effect on aqueous lead adsorption. J Chem Technol Biotechnol 76:1209-1215

Saka C, Sahin O, Kucuk M (2012) Applications on agricultural and forest waste adsorbents for the removal of lead (II) from contaminated waters. Int J Environ Sci Technol 9:379-394

Sari A, Tuzen M (2009) Kinetic and equilibrium studies of biosorption of $\mathrm{Pb}(\mathrm{II})$ and $\mathrm{Cd}(\mathrm{II})$ from aqueous solution by macrofungus (Amanita rubescens) biomass. J Hazard Mater 164:1004-1011

Singh J, Ali A (2012) Kinetics, thermodynamics and breakthrough studies of biosorption of $\mathrm{Cr}(\mathrm{VI})$ using arachis hypogea shell powder. Res J Chem Environ 16:69-79

Taty-Costodes VC, Fauduet H, Porte C, Delacroix A (2003) Removal of $\mathrm{Cd}(\mathrm{II})$ and $\mathrm{Pb}$ (II) ions, from aqueous solutions by adsorption onto sawdust of Pinus sylvestris. J Hazard Mater B105:121-142 
Thomas HC (1944) Heterogeneous ion exchange in a flowing system. J Am Chem Soc 66:1446-1664

Vaghetti JCP, Lima EC, Royer B, da Cunha BM, Cardoso NF, Brasil JL, Dias SLP (2009) Pecan nutshell as biosorbent to remove $\mathrm{Cu}(\mathrm{II}), \mathrm{Mn}(\mathrm{II})$ and $\mathrm{Pb}$ (II) from aqueous solutions. J Hazard Mater 162:270-280
Vinodhini V, Das N (2010) Packed bed column studies on Cr(VI) removal from tannery wastewater by neem sawdust. Desalination 264:9-14

$\mathrm{Yu}$ MH (2005) Environmental toxicology-biological and health effects of pollutants. CRC Press, Boca Raton 